\title{
Less Masculine, More Feminine dan Less Feminine, More Masculine: Laki-laki Mengekspresikan Androgini Melalui Fashion
}

\author{
Putri Kumalasari Fadly Wijayakusuma \\ Universitas Hasanuddin \\ Putks23@gmail.com
}

\begin{abstract}
Androgyny combines masculine and feminine characters at once. Despite the fact that the way one's talk, gestures, emotions, interests and talents are indicators of androgyny, fashion or the way they dress has become the main indicator. While the existing literatures deal more on characteristics, behavior, interests and talents, and self-representation through social media, this article is focused on how androgyny men exptress their gender through fashion.
\end{abstract}

This study was conducted in the city of Makassar which involved 12 male college students. They are varied based on age (between 20 and 24 years), and profession (master of ceremony, model, dancer, make up artist, disc jockey). Data was collected using in-depth interview, focus discussion group (FGD), and observation as the primary data sources as well website and social media (i.e. Instagram), as the secondary data sources.

The study indicates that androgynous men is not transgender because they did not want to become "like women", as transgender do. Besides, androgynous men classify themselves higher than transgender, from both appearance and social class. Although androgynous men may express their androgynousness through behavior, interests and talents, fashion is the most significant aspect that indicates a person's androgynousity. Androgynous men express androgyny more through fashion than others because through fashion their existence is easily recognized, as it is combining between masculine and feminine characters. Androgynous fashion is divided into two, less masculine-more feminine and less feminine-more masculine. Whether an androgynous man is more feminine or more masculine, depending on their performance and perception towards what is being performed. The motives of androgynous men are divided into two, the first is "because-to-motive" and "in-order to motive". While the former includes influencing by peer group, having sense of comfort, feeling self satisfaction, and being professional; the latter consists of expecting to be socially accepted and to be accepted as normal people.

Keywords: Androgyny, gender expression, fashion, masculine, and feminine.

\section{Pendahuluan}

Masyarakat Indonesia mungkin tidak asing lagi dengan istilah maskulin dan feminin. Maskulin dianggap sebagai karakter laki-laki yang identik dengan kejantanan, sementara feminin dianggap sebagai karakter perempuan yang identik dengan kefemininan. Keduanya terekspresikan melalui kepribadian, sikap, dan prilaku. Namun ekspresi gender tidak hanya sekedar maskulin dan feminin. Di antara keduanya ada androgini, yaitu gender yang diekspresikan dengan dua karakter sekaligus, yakni maskulin dan feminin (Waridah 2010:12).

Istilah androgini berasal dari bahasa Yunani kuno, andro berarti laki-laki dan gyne berarti perempuan (Bem 1974:35). Androgini ini merupakan suatu ekspresi yang dimana gender seseorang tidak rigid pada satu jenis kelamin, tapi berada di antara keduanya. Hal itu terlihat dari cara berbicara, gestur, emosi, 
minat dan bakat hingga cara berpakaian mereka. Seorang laki-laki yang berekspresi androgini tetap mengaku dirinya yaitu laki-laki walaupun memiliki sisi feminine dalam dirinya (Bem 1974:42).

Di Indonesia eksistensi androgini mulai berkembang, melalui media sosial. Istilah androgini mulai populer dilihat dari beberapa postingan selebgram ${ }^{1}$ yang mengekspresikan gaya sebagai seorang androgini. Dalam studinya tentang identitas androgini di media sosial, Oktavia (2020) mengungkapkan bahwa media sosial Instagram digunakan untuk mengomunikasikan siapa dirinya dan membentuk personal branding yang kuat. Hal itu menjadi pengaruh (influence) bagi orang-orang yang mengikutinya di Instagram pengaruh tersebut adalah kekuatan politis agar orang-orang dapat menerima keberadaan mereka, dan mengubah pemikiran dan mempengaruhi orang lain khususnya remaja di era informatika.

Studi Perdana, dkk. (2017), yang mengkaji sosok Jovi Adhiguna Hunter - seorang selebgram yang mengakui dirinya sebagai seorang androgini, menunjukkan bahwa Jovi Adhiguna Hunter telah melakukan upayaupaya untuk mendukung presentasi diri yang baik untuk membentuk visualisasi ideal seperti yang diharapkan penontonnya. Panggung depan narasumber adalah video pada channel Youtube miliknya sebagai sebuah wilayah yang digunakannya ketika menampilkan performanya di hadapan subscriber-nya. la mempresentasikan diri semaksimal mungkin, sehingga dirinya mampu menggiring pandangan penontonnya menuju "status kesan baik" yang dibentuknya selaku androgini. Ini terbukti dengan beberapa raihan yang diperolehnya, sehingga ia sering diundang sebagai pembicara dalam acara talk show, sebagai beauty and fashion influencer.

\footnotetext{
1 Selebgram merupakan singkatan dari selebriti Instagram, adalah istilah yang digunakan untuk
}

Usry (2018) dalam studinya tentang persepsi mahasiswa terhadap selebgram androgini mengungkapkan bahwa mereka tidak sulit menerima keberadaan selebgram androgini, namun mahasiswa FISIP USU kurang setuju dengan keberadaan selebgram androgini untuk menjadi idola (public figure). Sedangkan Anidya (2016) berargumentasi bahwa laki-laki androgini adalah laki-laki yang kehilangan identitas maskulinnya atas penggunaan atribut yang secara stereotip digunakan oleh perempuan, sebagaimana yang ditampilkan di media-media sosial dan mengindikasikan bagaimana identitas gender mencair (gender fluid).

Selain itu, androgini telah banyak dipromosikan dalam dunia fashion bahkan gaya androgini telah ada dan terkenal sejak tahun 1970-an. Beberapa artis laki-laki Amerika yang mempersentasikan dirinya dalam penampilan androgini adalah musisi Boy George, David Bowie, Prince dan Michael Jackson. Tidak hanya laki-laki, artis perempuan seperti Madonna, Cyndi Lauper, dan Annie Lennox juga dinilai mengkombinasikan gaya feminin sebagai bentuk pemberontakan dan kebebasan dari konstruksi gender (Waridah, 2010). Menurut Arnold (2001:113) dalam bukunya Fashion, Desire, and Anxiety, bahwa fashion androgini pada majalah busana di Jerman justru dijadikan acuan dalam berpakaian bagi perempuan maupun laki-laki, seperti pencitraan perempuan saat bekerja dalam majalah ditunjukkan bahwa perempuan menggunakan jas atau celana panjang dan tidak sedikit laki-laki yang menggunakan kosmetik. Arnold menekankan bahwa tidak ada batasan-batasan dari segi fashion antara lakilaki atau perempuan (genderless). Bagi Arnold, fashion androgini merupakan suatu bentuk pembebasan diri dari keterkekangan gender, dari konstruksi sosial yang menegakkan

merujuk pada selebriti Instagram yang memiliki fans/pengikut yang cukup banyak. 
perbedaan alamiah antara perempuan dan laki-laki, dari segi psikologis maupun perilaku.

Hal tersebut didukung oleh hasil penelitian Perkasa, dkk. (2017) yang mengungkapkan bahwa fashion androgini digunakan sebagai media untuk berkomunikasi, di mana dalam unsur-unsur fashion androgini, seperti pakaian, gaya rambut, hingga aksesoris secara sadar atau tidak disadari dapat menyampaikan suatu pesan akan emosi, perasaan, tingkah laku, atau pun kepribadian pemakainya. Fashion androgini juga dimanfaatkan sebagai media untuk mengekspresikan diri, membentuk diri, hingga membentuk identitas diri, juga berfungsi untuk membedakan seseorang dengan yang lainnya, baik dari segi profesi, hobi, hingga kegemaran..

Meski fenomena androgini sudah mulai berkembang, konsep androgini ini belum secara meluas dikenal oleh kebanyakan masyarakat di Indonesia. Androgini hanya dikenal di kelompok dalam lingkup terbatas, seperti dalam dunia seni dan fashion (Waridah 2010:11). Kurangnya pengetahuan masyarakat Indonesia mengenai konsep androgini menyebabkan androgini dipandang sebagai sebuah penyimpangan. Sebagian besar masyarakat menstereotipkan bahwa androgini adalah seorang transgender (Goenawan 2007:72). Laki-laki androgini kerap kali dihina dengan sebutan banci/bencong, alasannya karena laki-laki androgini sering mengenakan riasan wajah dan memakai atribut perempuan dalam penampilannya. Hal ini juga disebabkan oleh konstruksi sosial dari masyarakat patriakis bahwa dibanding perempuan, laki-laki lebih dibatasi dalam mengekspresikan emosi secara terbuka dan mereka harus tangguh dan berpenampilan jantan sepanjang waktu (Elliott 2019:3). Stereotipe ini yang kemudian mendorong para laki -laki androgini untuk lebih mengenalkan dirinya ke masyarakat.

Jika beberapa studi di atas lebih menitikberatkan pada bagaimana laki-laki androgini berupaya untuk memperkenalkan diri mereka melalui media sosial demi mengubah imej negatif di masyarakat, artikel ini berfokus pada ekspresi dan androgini yang ditampilkan melalui fashion karena fashion merupakan indikator utama androginitas seseorang. Sebagaimana diungkapkan oleh Perkasa, dkk. (2017), sayangnya penelitian ini hanya melibatkan perempuan untuk dipelajari nilai protektif dari sisi maskulin di dalamnya. Maka dari itu penelitian ini memilih laki-laki sebagai objek untuk di teliti sisi maskulin dan feminin dalam dirinya.

Pembahasan dalam artikel ini dibagi atas tiga bagian. Pertama, pembahasan difokuskan pada perbedaan androgini dan transgender. Bagian kedua mendemonstrasikan bagaimana laki-laki androgini mengekspresikan diri melalui fashion. Pembahasan pada bagian ketiga terfokus pada motif dibalik ekspresi diri androgini. Ketiga pembahasan ini bertujuan menjelaskan ekspresi androgini dalam konteks fashion yang belum terlalu dikenal dan banyak masyarakat khususnya di Indonesia. Dengan adanya penelitian ini, penulis berharap androgini dapat lebih mudah dipahami tanpa menimbulkan mispersepsi di masyarakat.

\section{Metode Penelitian}

Penelitian ini dilakukan antara bulan Desember 2019 dan Agustus 2020 di Kota Makassar sebagai kota metropolitan dengan populasi yang multikultural dan eksistensi keberagaman gender di Kawasan Timur Indonesia (KTI) cukup signifikan.

Penelitian ini melibatkan 12 laki-laki androgini, 11 diantaranya adalah mahasiswa dan seorang makeup artist. Tujuh di antara mahasiswa bekerja sampingan sebagai dancer dan dua orang sebagai model, satu orang disc jokey, dan satu orang lainnya pembawa acara atau MC, sebagaimana dijabarkan pada Tabel 1 berikut ini: 
Less Masculine, More Feminine dan Less Feminine, More Masculine: Laki-laki...

\begin{tabular}{|c|c|c|c|c|}
\hline \multicolumn{5}{|c|}{ Tabel 1. Informan Penelitian } \\
\hline No & Nama & $\begin{array}{l}\text { Umur } \\
\text { (Tahun) }\end{array}$ & Status & Pekerjaan \\
\hline 1. & Adhe & 22 & Mahasiswa & MC dan Model \\
\hline 2. & Agung & 20 & Mahasiswa & $\begin{array}{c}\text { Makeup artist dan Dancer (Botty } \\
\text { Boyz) }\end{array}$ \\
\hline 3. & Joshua & 22 & Mahasiswa & Dancer (Botty Boyz) \\
\hline 4. & Fiqri & 21 & Mahasiswa & Dancer (Botty Boyz) \\
\hline 5. & Irvan & 21 & Mahasiswa & - \\
\hline 6. & Rajif & 23 & Mahasiswa & - \\
\hline 7. & Ami & 20 & Mahasiswa & Dancer (Botty Boyz) \\
\hline 8. & Idris & 20 & Mahasiswa & - \\
\hline 9. & Ikky & 22 & Mahasiswa & $\begin{array}{c}\text { Didc Jokey dan Dancer } \\
\text { (Botty Boyz) }\end{array}$ \\
\hline 10. & Risqi & 22 & Mahasiswa & Model \\
\hline 11. & Jeje & 22 & Mahasiswa & Dancer (Botty Boyz) \\
\hline 12. & Abe & 24 & Mahasiswa & - \\
\hline
\end{tabular}

Data diperoleh melalui wawancara mendalam, focus discussion group (FGD), dan observasi sebagai sumber data primer serta sumber data sekunder melalui website dan media sosial (Instagram). Observasi dilakukan untuk mengamati ekspresi gender dari pelaku androgini meliputi penampilan atau cara berpakaiannya yang dituangkan melalui fashion. Wawancara mendalam dilakukan untuk mengeksplorasi perbedaan androgini dengan transgender, bentuk ekspresi androgini yang dituangkan melalui fashion, alasan, dan tujuan androgini mengekspresikan dirinya melalui fashion. Teknik FGD dilakukan terhadap anggota kelompok androgini bernama Botty Boyz dengan jumlah peserta sembilan orang. Adapun topik-topik diskusi FGD konsep diri androgini, bentuk ekspresi androgini, sisi feminin dan maskulin androgini, perbedaan androgini dan transgender, dan motif androgini mengekspresikan dirinya melalui fashion.

Analisis data dimulai dengan menyusun secara sistematis data yang diperoleh dari teknik pengumpulan data yang berbeda (observasi, wawancara dan FGD) yang berupa catatan observasi dan transkrip wawancara dan FGD. Data tersebut dibaca secara menyeluruh dan mencari tema-tema utama yang muncul, konsep diri androgini, perbedaan androgini dengan banci/bencong atau transgender, dan fashion sebagai bentuk dari ekspresi para pelaku androgini beserta motifnya.

Izin penelitian diperoleh melalui Kantor Dinas Penanaman Modal dan Pelayanan Terpadu Satu Pintu bidang penyelenggaraan pelayanan perizinan. Selanjutnya, surat perizinan diteruskan ke kantor Balaikota Makassar karena penelitian ini dilakukan di Kota Makassar. Informan yang terlibat awalnya diperoleh dari anggota dari sebuah kelompok androgini, yang kemudian memperkenalkan laki-laki androgini lainnya secara snowball sampling. Sebelum wawancara dimulai, masing-masing dijelaskan maksud, tujuan, dan manfaat penelitian, serta menanyakan kesediaan mereka untuk diwawancarai dan direkam saat proses wawancara berlangsung. Semua nama yang digunakan adalah nama asli dan semua foto mereka yang ditampilkan adalah foto asli dan atas izin mereka (by consent). 


\section{Androgini vs Transgender}

Androgini adalah istilah yang digunakan untuk menunjukkan ekspresi gender di mana karakter maskulin dan feminin menyatu. Ekspresi androgini meliputi perilaku, minat dan bakat, serta penampilan atau cara berpakaiannya. Jika dilihat dari segi perilaku, laki-laki androgini cenderung memiliki karakter feminin, namun tetap mempertahankan sisi maskulinnya. Hal ini terlihat dari cara berbicara yang halus, gestur tubuh kemayu, seperti menutup mulut ketika tertawa atau menyelipkan rambut ke belakang telinga serta duduk dengan memangku kaki. Warna yang disukai seperti warna pink, hingga emosi mereka (seperti sensitif dan mudah menangis). Kemudian jika dilihat dari minat dan bakatnya, laki-laki androgini cenderung menyukai aktivitas yang secara stereotip dikaitkan dengan perempuan, seperti memasak, menjahit, dan menari, di satu sisi. Namun, lakilaki androgini juga menampakkan karakter yang distereotipkan sebagai karakter maskulin, seperti mandiri, ambisius, percaya diri; dan prilaku maskulin, seperti berjalan tegak; serta kegiatan maskulin, seperti berbalap mobil, bermain bola, berolahraga, merokok, dll.

Abe (24 tahun), misalnya, merasa bahwa jika berbicara dirinya lemah lembut dan sangat sensitif. Namun, ia juga memiliki sifat mandiri dan pekerja keras. Selain itu, walaupun menyukai warna pink dan rajin membersihkan rumah, ia juga suka bermain sepak bola yang dianggapnya sebagai olahraga maskulin. Agung (20 tahun), contoh lain dari laki-laki androgini, yang memiliki karakter ceria, ekspresif, humoris dan cerewet yang cukup berbeda dengan karakter laki-laki pada umumnya serta menyukai dance dan makeup. Namun, ia juga memiliki suara yang berat, sangat ambisius, agresif, tidak mudah tersinggung, dan percaya diri, serta memiliki kebiasaan merokok yang dianggap sebagai

2 Blazer adalah sejenis jaket dengan potongan casual. karakter maskulinnya. Sedangkan Risqi (21 tahun) merasa secara mental mengadaptasi hampir seluruh sifat-sifat maskulin, seperti tidak mudah menangis, berjalan tegak, dan gemar berolahraga agar badannya kekar. Prilaku femininnya ditampakkan melalui gestur tubuhnya, misalnya, Risqi sering kali menutup mulutnya ketika tertawa, menyelipkan rambutnya ke belakang telinga, serta duduk dengan memangku kaki.

Selain itu, androgini juga mengekspresikan dirinya melalui penampilan. Menurut Adhe (22 tahun), seorang androgini memiliki tampilan luar maskulin dan feminin sekaligus, seperti ia yang gemar memakai blazer $^{2}$ perempuan dan celana kain laki-laki, ditambah penggunaan beberapa assesori, seperti cincin set perempuan ala Korea yang terkesan feminin, ring belt atau ikat pinggang yang memiliki kepala atau bagian gesper berbentuk dua cincin yang banyak dikenakan oleh perempuan. la juga mengenakan jam tangan laki-laki, tas bahu perempuan, dan sepatu kets khusus laki-laki yang semuanya bermerek (branded). Adhe beranggapan bahwa penampilannya adalah bentuk ekpresi dari keandroginiannya, dan ini membuat penampilannya menjadi unik.

Penampilan laki-laki androgini yang mengombinasikan aspek feminin dan maskulin menyebabkan mereka seringkali diidentikkan sebagai transgender, yang secara lokal diistilahkan banci atau bencong. Padahal androgini mengacu pada ekspresi gender seseorang yang dalam konteks ini ditampilkan melalui fashion, bukan identitas gender, bukan orientasi seksual. Sedangkan transgender merujuk pada orang yang identitas gendernya tidak cocok dengan jenis kelamin kodratinya (given), jenis kelamin yang ditentukan oleh sifat fisik mereka (Altilio dan Green 2011:80), dan tertarik pada orang yang secara biologis adalah laki-laki. Kaum transgender kerap 
merasa dirinya lahir dalam tubuh yang salah (Weger 2016:229). Berbeda dengan laki-laki androgini yang tetap memandang dirinya sebagai laki-laki dan tidak ingin mengubah dirinya menyerupai perempuan walaupun ada unsur feminin yang ditampilkannya (Gwendolyn 2013:157).

Meskipun keberadaan androgini masih dianggap sebagai sebuah penyimpangan karena penampilan mereka yang berbeda dar tampilan gender normatif. Tidak mengherankan jika ada yang terang-terangan menunjukkan ketidaksukaannya terhadap gaya androgini bahkan sampai menghujat lakilaki androgini dengan panggilan seperti bencong, banci kaleng hingga "mahluk jadijadian". Padahal androgini dan transgender adalah dua klasifikasi gender yang berbeda, dan laki-laki androgini tidak ingin dipertukarkan dengan transgender.
Seorang model bernama Dena Rachman, misalnya, yang terlahir dengan nama Renaldy Denada Rachman telah memutuskan untuk mengganti penampilannya. Sejak remaja Dena memang telah merasakan bahwa fisik dan jiwanya cenderung ke perempuan. Dena memulai kariernya di dunia hiburan ketika masih duduk di bangku sekolah dasar sebagai bintang iklan dan penyanyi cilik. la juga menjadi pembawa acara Krucil di SCTV dan membintangi sejumlah sinetron. Menginjak usia remaja, ia mulai jarang terlibat dalam dunia entertain dan memilih untuk fokus pada pendidikannya. la kembali berprofesi sebagai seorang model setelah dirinya memutuskan untuk berpenampilan seperti perempuan (lihat Gambar 1).

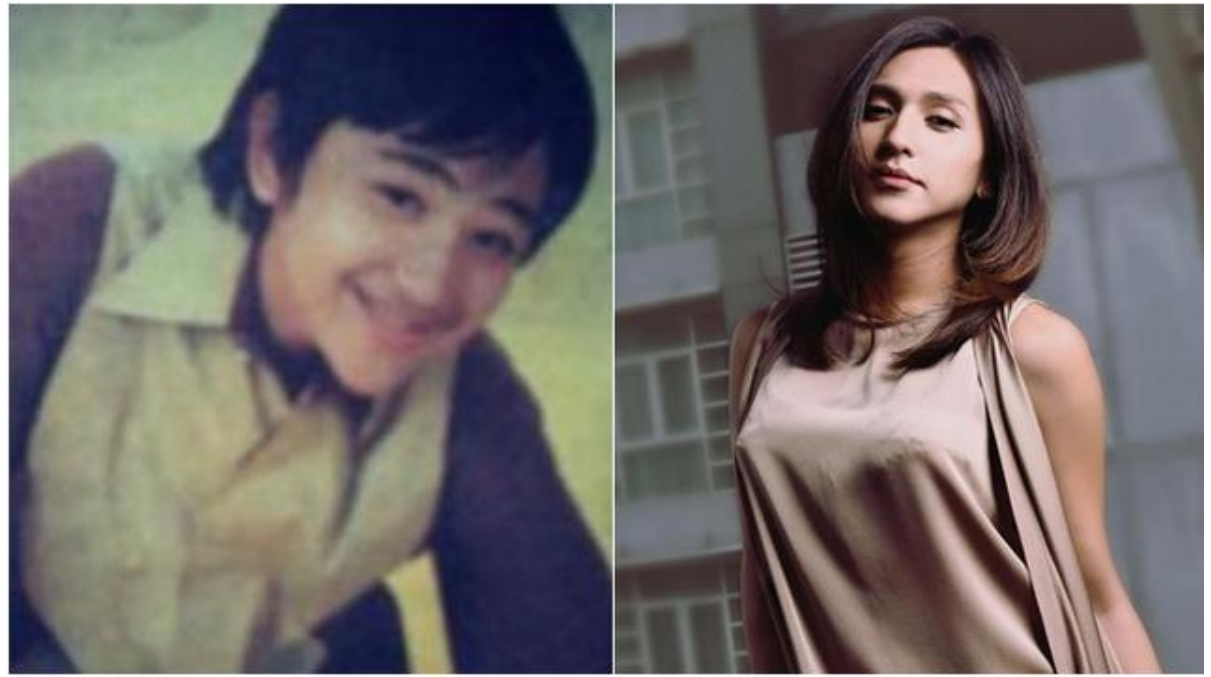

Gambar 1. Dena Rachman ${ }^{3}$

Dena Rachman dikategorikan sebagai seorang transgender karena penampilannya sudah menyerupai perempuan, ia juga merasakan jiwanya lebih cenderung ke perempuan ketimbang laki-laki. Meskipun demikian, ia tidak bermaksud melakukan operasi ganti kelamin (transeksual). Di Indonesia, tidak banyak transgender yang

\footnotetext{
${ }^{3}$ https://www.liputan6.com/showbiz/read/4014808/4-
} fakta-perjalanan-hidup-dena-rachman-sebelum- mengubah kelaminnya, seperti Vivian, Dorce Gamalama.

Androgini selalu melihat diri mereka berbeda dan lebih tinggi levelnya dibandingkan dengan transgender. Oleh karenanya, jargon "saya bukan banci" begitu menggema di kalangan mereka yang menekankan keberbedaan laki-laki androgini dengan 
transgender. Temuan penelitian ini menunjukkan dua aspek yang secara tegas membedakan antara laki-laki androgini dan transgender, yakni: laki-laki androgini tidak ingin menjadi perempuan dan androgini lebih modis dari banci/bencong, sebagaimana yang akan didiskusikan pada sub-sessi berikut ini.

\section{Tidak Ingin Menjadi Perempuan}

"Tidak ingin menjadi perempuan" adalah ekspresi yang umum digunakan oleh laki-laki androgini untuk menunjukkan bahwa mereka, meskipun memiliki sisi feminin secara fisik maupun penampilan, namun secara kodrati mereka adalah laki-laki.

Walaupun seringkali berpenampilan menggunakan atribut yang feminin, Jeje (22 tahun) tidak akan mengenakan pakaian yang khusus bagi perempuan, seperti bra (beha). la juga menganggap dirinya androgini karena orang yang melihatnya masih mengenali dirinya sebagai laki-laki. la juga tidak mengubah bentuk tubuhnya menjadi "seperti perempuan".
Agung (20 tahun) mengungkapkan bahwa kebisaaannya berdandan membuat orang tuanya mengira putranya adalah seorang transgender, mereka bahkan tak keberatan jika anaknya mau menjalani proses transisi kelamin. Namun jawaban dari Agung malah mengejutkan mereka, ia mengatakan bahwa ia hanya laki - laki yang memakai riasan. Agung menikmati seni berdandan, dan jadi laki - laki yang melakukannya. Agung juga percaya diri sebagai laki - laki dan akan selalu jadi laki laki.

Hal serupa diungkapkan Idris (20 tahun), bahwa walaupun gemar berdandan, ia tetap melihat dirinya sebagai sosok laki-laki. la merasa nyaman dengan fisiknya sebagai lakilaki, dan tidak pernah berfikir untuk menjadi seorang perempuan. Baginya, dandanan adalah seni yang tak mengenal gender (genderless). Berikut hasil makeup Idris yang dianggapnya sebagai suatu seni dan sama sekali tidak membuatnya nampak seperti perempuan (lihat Gambar 2):

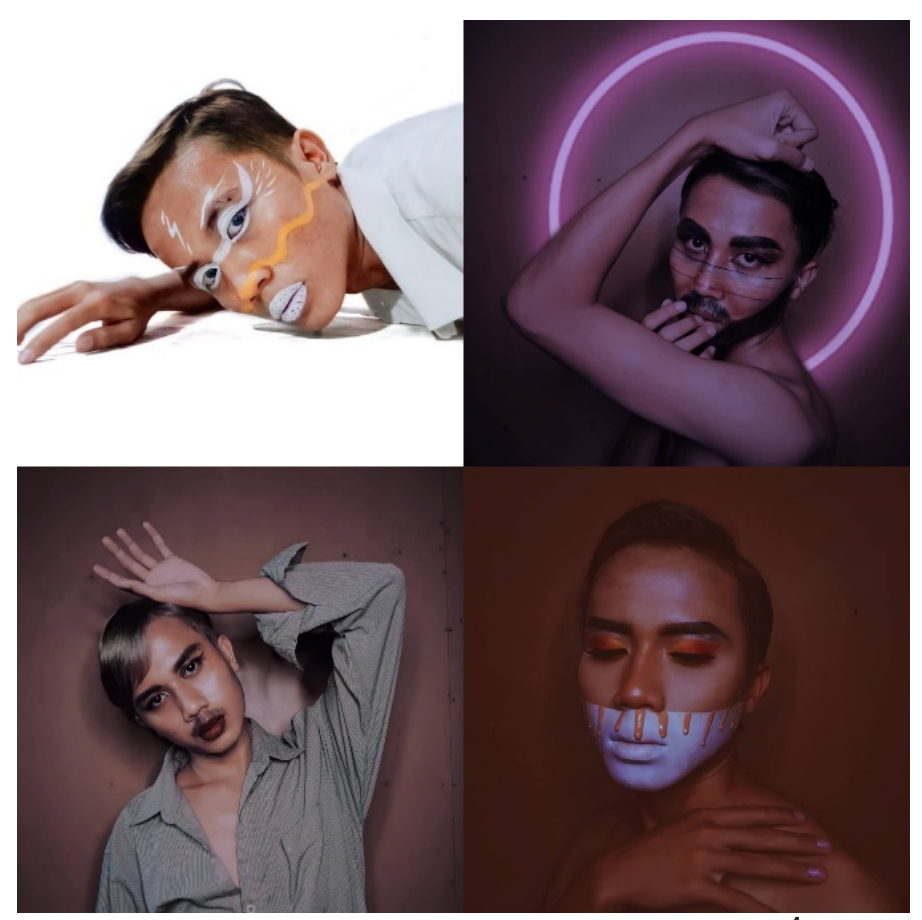

Gambar 2. Idris dan seni merias wajah ${ }^{4}$

${ }^{4}$ https://www.instagram.com/alfndidris/ dikses pada tanggal 25 Juni 2020. 
Less Masculine, More Feminine dan Less Feminine, More Masculine: Laki-laki...

Pernyataan-pernyataan di atas mengindikasikan bahwa meskipun laki-laki androgini memiliki dua sisi, maskulin sekaligus feminin, mereka tetap melihat diri mereka sebagai laki-laki bukan perempuan.

\section{Lebih Modis Dari Banci/Bencong}

Panggilan bencong, banci, hingga banci kaleng terhadap androgini membuat gerah para lakilaki androgini. Banci kaleng adalah istilah cercaan untuk pengamen transgender atau waria yang berpakaian dan berdandan menyolok yang berdiri di pinggir jalan atau lampu merah. Mereka menyanyi sambil membawa semacam kaleng yang dijadikan alat musik, berpakaian seksi, dan merayu orang lain agar memberi uang ${ }^{5}$ (lihat Gambar 3 ), sesuatu yang jauh berbeda dengan gambaran androgini.

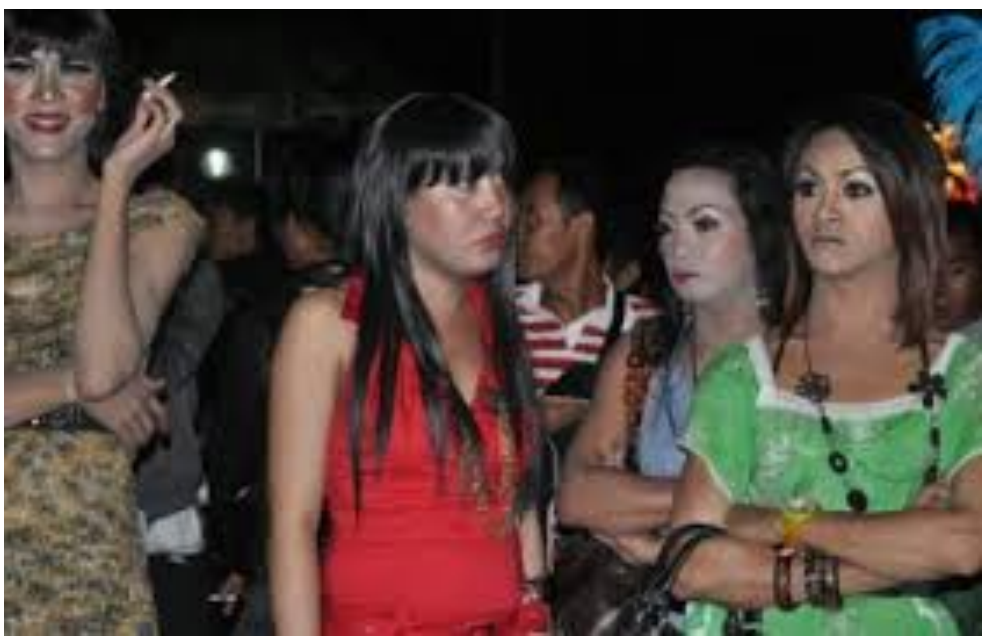

Gambar 3. Penampilan banc/bencongi ${ }^{6}$

Laki-laki androgini umumnya berasal dari golongan menengah ke atas, sehingga mereka bisa lebih leluasa untuk menunjukkan androginitas mereka melalui penampilan. Lakilaki androgini menganggap penampilan mereka jauh lebih modis dan berkelas dibandingkan dengan bencong/banci. Mereka berpenampilan berkelas untuk menunjukkan kelas sosial mereka (Chaney 2004:112), dan untuk membedakan diri mereka dari orang lain, terutama dari banci, yang umumnya dianggap berasal dari masyarakat golongan menengah ke bawah.
Adhe (22 tahun) mengakui bahwa mengenakan pakaian yang bermerek, seperti Zara, PullnBear, H \& M, Kenzo, Nike, Adidas, Coach, dll. la juga kerap tampil modis, yaitu tampil sesuai dengan tren atau penampilan yang modern, seperti mengenakan kemeja kerah cuban, dimana tren fashion ini menjadi tren mode musim panas tahun 2020 di luar negeri maupun dalam negeri ${ }^{7}$. Berbeda dengan kemeja pada umumnya, kemeja ini memiliki bentuk kerah yang unik, dan biasanya berlengan pendek. Oleh karenanya, ia merasa berbeda dengan banci yang menurutnya

\footnotetext{
${ }^{5}$ https://www.kompasiana.com/pujinurani/552fd7ff6ea8348a408b46b1/banci-kaleng-dan fragmkemacetan\#: :text=Pengamen\%20laki\%2Dlaki\%20berpenampilan\%20perempuan,ini\%20sering\%20dijul uki\%20Banci\%20Kaleng, diakses tanggal 2 Juli 2020.

${ }^{6} \mathrm{https}: / /$ www.metropolitan.id/2018/07/banci-mewabah-di-citereup/, diakses tanggal 2 Juli 2020.

${ }^{7}$ https://www.cekaja.com/info/tren-fashion-pria-2020-simpel-namun tetapmemikat\#: :text=Tren\%20fashion\%20pria\%202020\%20vang\%20pertama\%20adalah\%20kemeja\%20kerah \%20cuban,musim\%20panas \%20di\%20luar\%20negeri.\&text=Untuk\%20memadukannya $\% 2 \mathrm{C} \% 20$ kamu $\% 20 \mathrm{bisa} \%$ 20menggunakan,kulit\%20dan\%20juga\%20sepatu\%20kulit, diakses tanggal 2 Juli 2020.
} 
membeli baju mereka di pasar yang berupa pakaian-pakaian bekas perempuan, seperti tank-top, legging ketat dengan warna yang terang. Bagaimana laki-laki androgini mengekspresikan keandroginian mereka melalui fashion?

\section{Androgini: Ekspresi Gender dan Fashion}

Fashion adalah sebuah ekspresi estetika yang populer pada waktu, masa, tempat tertentu dan dalam konteks tertentu, terutama pada pakaian, sepatu, gaya hidup, aksesoris, riasan wajah, gaya rambut, dan proporsi tubuh (Lipovetsky 2010:65). Fashion merupakan bentuk ekspresi diri seseorang dalam berpenampilan (Barnard 2007:39).

Meskipun perilaku, minat dan bakat dapat menjadi aspek yang menunjukkan androginitas seseorang, namun fashion merupakan aspek yang paling signifikan yang mengindikasikan androginitas seseorang.

Temuan penelitian ini menunjukkan bahwa laki-laki androgini lebih mengekspresikan penampilannya melalui fashion. Bahkan banyak di antara mereka mengakui bahwa istilah androgini awalnya diketahui melalui dunia fashion. Risqi (22 tahun), misalnya, mengungkapkan bahwa ia mengetahui istilah androgini ketika ia menjadi model. Ketika itu Risqi diminta tampil di sebuah fashion show atau acara pagelaran busana dengan konsep androgini yang sebelumnya belum pernah ia dengar. Setelah dijelaskan oleh penyelenggara acaranya bahwa fashion androgini itu memadukan busana laki-laki dan perempuan, Risqi baru menyadari bahwa selama ini ia berekspresi androgini dalam fashion-nya sehari-hari.

Pembahasan berikut ini menyangkut tentang fashion sebagai pilihan untuk mengekspresikan androginitas seseorang dan bagaimana bentuk fashion, serta jenis fashion yang digunakan untuk mengekspresikan androginitas.

\section{Fashion Sebagai Pilihan Ekspresi}

Dalam mengekspresikan diri, laki-laki androgini memiliki beragam alasan untuk memilih fashion sebagai bentuk ekspresi diri. Adhe (22 tahun), misalnya, beranggapan bahwa fashion merupakan salah satu upaya mengomunikasikan status kelas sosial kepada masyarakat. Adhe menggunakan fashion untuk mengekspresikan diri agar dipandang orang, diakui keberadaannya, membentuk imej dirinya, hingga membentuk identitasnya. Hal ini berkelindan dengan pandangan Chaney (1996:91), bahwa dengan gaya androgini, penampilannya terlihat lebih fashionable dan menandakan eksistensinya sebagai manusia modern.

Fashion juga dianggap sesuatu yang sangat penting dalam kegiatan sehari-hari. Dengan memperhatikan fashion dalam berpenampilan, secara tidak langsung ini menjadi salah satu upaya memengaruhi orang lain untuk menilai diri seseorang. Diasumsikan bahwa semakin baik cara berpenampilan seseorang, semakin baik pula penilaian orang lain terhadap pengguna fashion tersebut (Hendariningrum, 2014:26). Selain itu, menurut Ikky (20 tahun), fashion merupakan media yang paling mudah diidentifikasi oleh seseorang dan melalui fashion mereka dapat menuangkan kreativitas dalam penampilan mereka yang menimbulkan rasa percaya diri. Hal serupa diungkapkan Adhe (22 tahun), bahwa fashion dapat membuat orang menjadi lebih kreatif dalam menampilkan diri. Adhe mulai menyukai fashion androgini-yang menggabungkan unsur feminin dan maskulinsaat remaja dan makin berkembang ketika ia terjun dalam dunia modelling dan setelah aktif menjadi pembawa acara, hingga menjadikan fashion androgini sebagai his daily fashion.

Meskipun fashion itu bergender, namun bagi laki-laki androgini, mengekspresikan fashion itu tanpa batas karena fashion adalah sesuatu yang dikonstruksikan secara sosial (social 
construction), bukan sesuatu yang kodrati (given), sehingga bisa berubah-ubah. Agung (20 tahun), misalnya, mengatakan bahwa fashion androgini tidak terikat dengan satu gender dan ini membuat penggunanya merasa lebih bebas dalam memilih atribut dalam berpenampilan. Menurut Agung, tidak ada batasan dalam fashion, siapa saja bebas berpenampilan, pakaian tidak mengenal gender. Itu menjadi dasarnya memilih fashion sebagai media untuk mengekspresikan gender. Pertanyaannya adalah bagaimana bentuk fashion androgini?

\section{Bentuk Fashion Androgini}

Dalam dunia fashion, penampilan androgini dikenal dengan sebutan gaya androgini (androgynous style) (Pradika, 2019:7). Dalam gaya androgini, laki-laki tidak dibatasi dengan tampilan bergaya maskulin (seperti celana, jas, bertatto), mereka juga mengenakan busana perempuan (seperti sack dress, rok) dan berdandan. Salah satu contohnya adalah penampilan Harry Styles di acara Met Gala. Met Gala adalah acara penggalangan dana tahunan yang diadakan pada hari Senin pertama di bulan Mei sejak tahun 1948, dan dana yang terkumpul dari acara ini akan diberikan kepada Metropolitan Museum of Art Costume Institute. Selain penggalangan dana, acara ini juga merayakan pembukaan pameran fashion Metropolitan Museum Art yang terbaru. Setiap tahunnya, Met Gala diramaikan oleh deretan aktor, aktris, model, musisi, dan desainer papan atas yang tampil sesuai dengan tema pameran fashion tersebut. yang membuat mereka menjadi pusat perhatian. ${ }^{8}$

Harry berjalan di karpet merah di Metropolitan Museum of Art, New York, Amerika Serikat (Senin, 6 Mei 2019) bergaya androgini dengan mengenakan produk pakaian Gucci berupa atasan hitam menerawang berhias renda dengan sejumlah assesoris, seperti anting-anting mutiara yang menggantung di sebelah telinga dan memakai cat kuku berwarna hitam dan biru serta cincin emas dengan inisial namanya. Namun, Harry juga menampakkan sisi maskulinnya dengan mengenakan celana high waisted berwarna hitam dan sepatu bertumit tinggi berwarna hitam, dan tatto di dada dan lengannya, seperti terlihat pada Gambar 4 dibawah ini.
${ }^{8}$ https://www.cosmopolitan.co.id/article/read/5/201 9/15830/met-gala-2019-sejarah-tema-dan-tamuundangan diakses pada tanggal 30 november 2020 


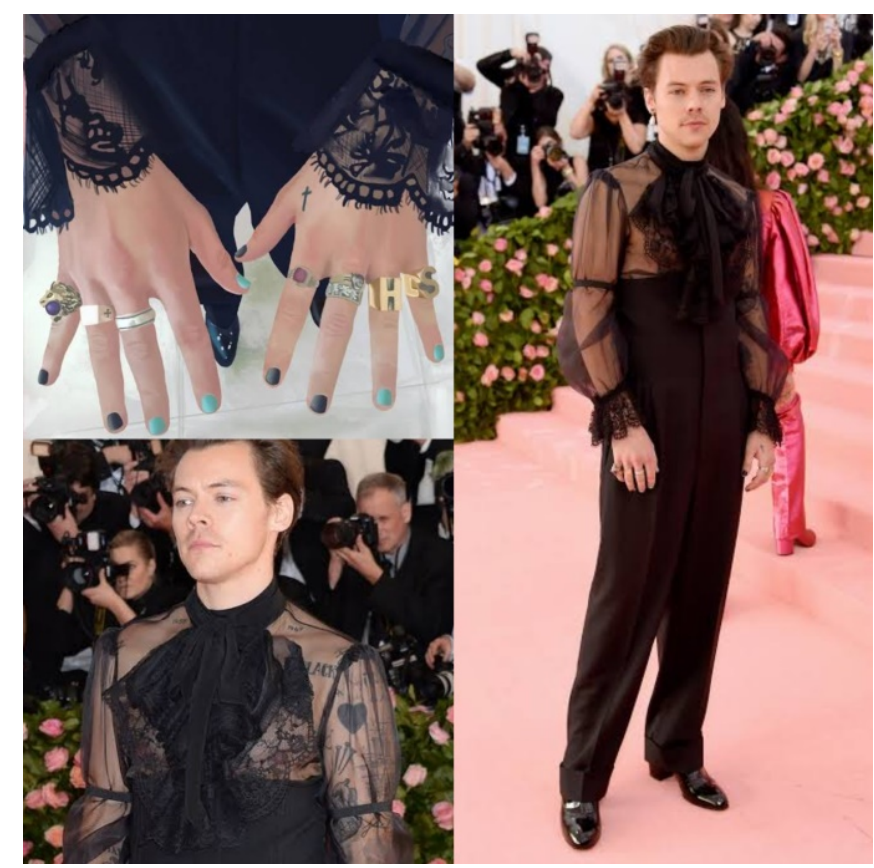

Gambar 4. Gaya androgini Harry Styles di Met Gala $2019^{9}$

Sandra Bem (1977:44) menyatakan bahwa laki-laki androgini dapat memiliki skor yang sama sama tinggi dalam dua karakteristik, memiliki porsi yang sama antara karakter maskulin dan feminin dalam satu tubuh. Namun, hasil penelitian ini mengindikasikan bahwa androgini di Kota Makassar memiliki karakter maskulin dan feminin dalam diri lakilaki androgini dengan porsi yang berbeda, yakni karakteristik less feminine, more masculine dan less masculine, more feminine.

\section{Less Feminine, More Masculine}

Laki-laki androgini yang dikategorikan sebagai less feminine, more masculine menunjukkan karakteristik maskulin yang dominan. Rajif (23 tahun), misalnya, cenderung menggunakan produk skincare khusus perempuan dengan alasan kulitnya yang sensitif dan menganggap produk skincare khusus laki-laki tidak cocok dengan kondisi kulitnya yang mudah berjerawat. Rajif juga gemar melakukan perawatan di klinik kecantikan. Kebisaaan Rajif merawat wajah dianggapnya sebagai aktivitasnya yang bersifat feminin. Walaupun demikian tujuannya melakukan perawatan wajah bukan untuk terlihat menyerupai perempuan, ia tetap ingin terlihat tampan sebagaimana laki-laki maskulin. Rajif juga berpendapat bahwa penggunaan skincare yang diidentikkan dengan perempuan itu tidak tepat, dan menggunakan skincare yang dirancang khusus perempuan tidak salah, semua tergantung jenis kulit masing-masing. Selain penggunaan skincare, Rajif juga memanjangkan dan mewarnai rambutnya yang membuatnya terlihat feminin, tapi tetap mempertahankan kumis sebagi simbol maskulin. Dari segi pakaian Rajif menganggap dirinya masih terlihat maskulin, ia menyukai sweater dan kemeja dengan motif abstrak dengan warna cerah, seperti terlihat pada Gambar 5 berikut ini.

\footnotetext{
${ }^{9}$ https://www.bollywoodlife.com/news-gossip/met-gala-2019-harry-styles-earns-admiration-on-social-media-ashe-rocks-pearls-and-breaks-gender-stereotypes-read-tweets-1406884/. diakses pada tanggal 23 April 2020.
} 


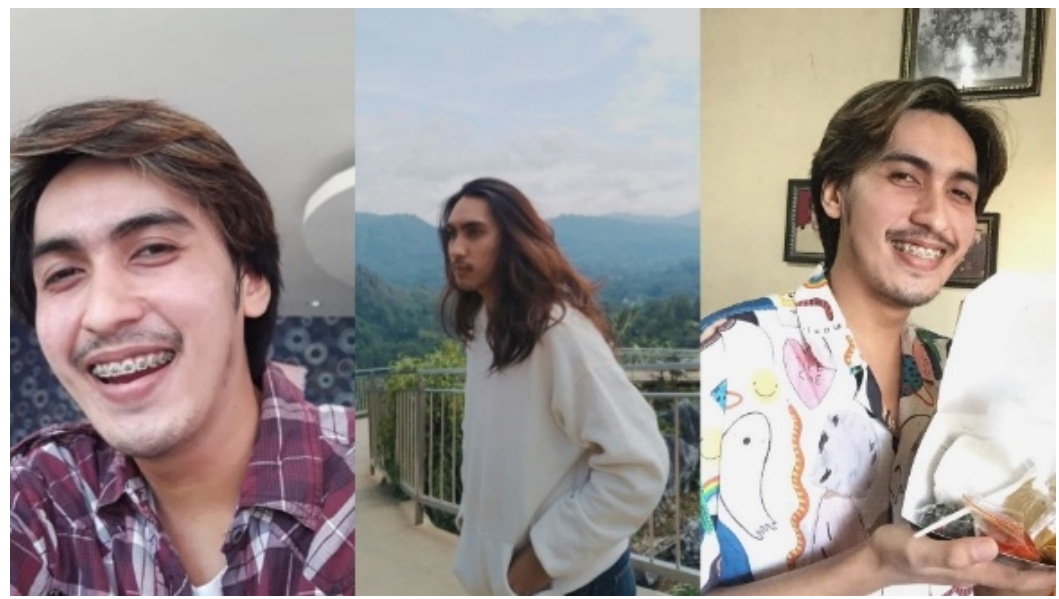

Gambar 5. Gaya androgini Rajif ${ }^{10}$

Begitu pula dengan Adhe (22 tahun) yang gemar berdandan sederhana dan terkesan natural untuk menutupi kekurangan yang ada pada wajahnya, seperti kantung mata, jerawat dan noda hitam bekas jerawat. Namun, baginya berdandan bukan untuk terlihat "cantik", melainkan untuk membuat wajahnya, sebagaimana Rajif, terlihat lebih bersih dan tampan. Adhe juga menggunakan pelembab bibir agar bibirnya tidak kering. Meskipun Adhe berdandan, ia tetap merasa penampilannya tidak kehilangan sisi maskulinnya. Adhe gemar mengenakan satchel bag atau tas yang memiliki bentuk persegi panjang yang dilengkapi dengan tali pendek untuk dijinjing maupun tali panjang yang bisa diselempangkan, yang biasanya digunakan oleh perempuan. la juga gemar menggunakan assesori, seperti jam tangan dan cincin. Dari segi pakaian, Adhe gemar memadukan busana laki-laki dan perempuan dan lebih memerhatikan bentuk pakaian tersebut. Salah satu model pakaian yang digemarinya adalah perpaduan antara kimono ikat dan kemeja serta celana panjang. Menurutnya, gaya berpakaian seperti ini menunjukkan sisi maskulin sekaligus feminin (lihat Gambar 6).

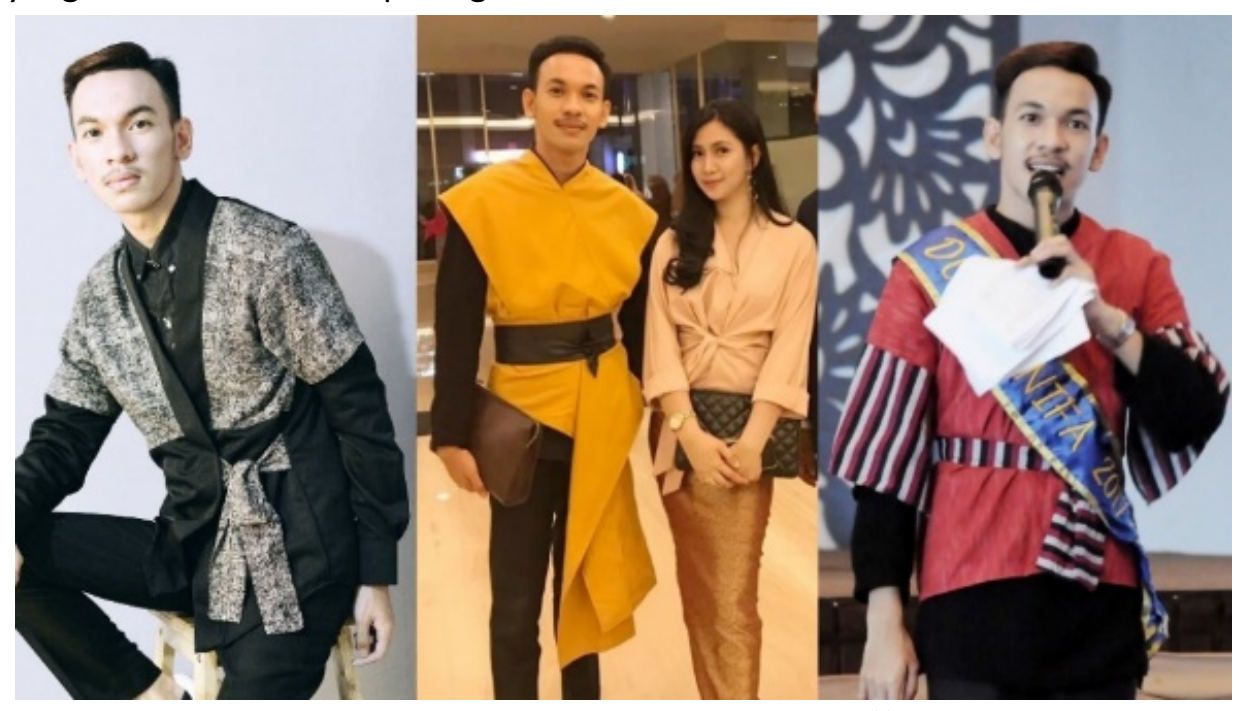

Gambar 6. Gaya androgini Adhe Caesaryo ${ }^{11}$

\footnotetext{
10 https://www.instagram.com/muhammad_rajif/, diakses tanggal 25 Mei 2020.

${ }^{11}$ https://www.instagram.com/adhe caesaryo/), diakses tanggal 14 Februari 2020.
} 
Rajif (23 tahun) dan Adhe (22 tahun) merasa karakteristik maskulin dalam diri mereka lebih dominan dibandingkan dengan karakter feminine. Ini dapat dilihat dari penampilan mereka yang hampir menyerupai laki-laki maskulin pada umumnya, seperti berjalan yang tegak, suara yang berat, dan pakaian serta assesoris yang maskulin. Sisi maskulin dari penampilan Rajif dapat dilihat dari kumis, kemeja kotak-kotak, celana jins, dan sepatu Adidas for men yang sering ia gunakan. Sedangkan karakter feminin Rajif hanya ditampilkan melalui perawatan wajah secara teratur tetapi tidak menggunakan makeup dan rambut yang dipanjangkan dan diwarnai. Sedangkan sisi maskulin Adhe dapat dilihat juga dari kumis, kemeja hitam, celana katun hitam, sepatu Vans, Nike, dan Adidas for men. Sedangkan sisi femininnya dapat dilihat dari penggunaan dandanan tipis, kimono ikat, yang dikombinasikan dengan assesoris perempuan, seperti satchel bag warna-warni dan cincin mutiara. Walaupun Adhe yang gemar memadukan busana laki - laki dan perempuan, ia tetap memperhatikan bentuk pakaian tersebut sehingga ketika dipadukan tidak terlihat lebih dominan feminin.

\section{Less Masculine, More Feminine}

Kategori less masculine, more feminine menunjukkan karakteristik feminin lebih dominan daripada karakteristik maskulin. Agung (21 tahun), Ikky (21 tahun), DAN Joshua (22 tahun) adalah contoh laki-laki androgini yang lebih menonjolkan karakteristik feminin mereka dibandingkan karakteristik maskulin. Karakteristik feminin ditampilkan dengan makeup agak tebal, mewarnai rambut, serta busana yang menyolok, dan membuat mereka seringkali dikategorikan sebagai bencong, banci atau transgender. Padahal mereka mempertahankan karakteristik maskulin mereka yang dapat dilihat dari kumis dan rambut pendek.

Agung (20 tahun), yang bekerja sebagai makeup artist, gemar berpenampilan dengan strong makeup (dandanan tebal), ia senang berkreasi melalui makeup. Dalam kesehariannya Agung menggunakan lebih banyak produk makeup dibanding Adhe, seperti foundation (pengalas bedak), concelear (penyamar noda gelap pada wajah), compact powder (bedak padat), blush on (perona pipi), eyeshadow (perona mata), highlighter (bubuk yang memantulkan cahaya) yang memberi kesan berkilau pada wajah, serta maskara, pensil alis, dan lipstick warna natural karena melalui dandanan ia ingin menampilkan sisi feminin dari dirinya. Namun, Agung tetap mempertahankan model rambutnya yang pendek dan kumis tipis untuk menampilkan sisi maskulinnya. Kemudian dari segi pakaian, Agung gemar menggunakan, turtleneck ${ }^{\mathbf{1 2}}$, dan pakaian set (atasan dan bawahan yang sama). Agung senang menggunakan tas model clutch, sling bag ${ }^{13}$, waist bag ${ }^{14}$ dan sepatu sneakers atau sepatu tumit tinggi, dan memakai assesoris berupa kalung, jam tangan, dan ikat pinggang (lihat Gambar 7).

\footnotetext{
${ }^{14}$ Jenis tas yang bisanya dikenakan di sekitar pinggang

dan pinggul.
}

12 Baju berkerah tinggi yang menutupi seluruh leher
dan dapat dilipat setengahnya sampai setinggi jakun.
${ }^{13}$ Tas berukuran kecil disertai tali panjang untuk
disampirkan pada bahu atau dengan cara disilangkan. 


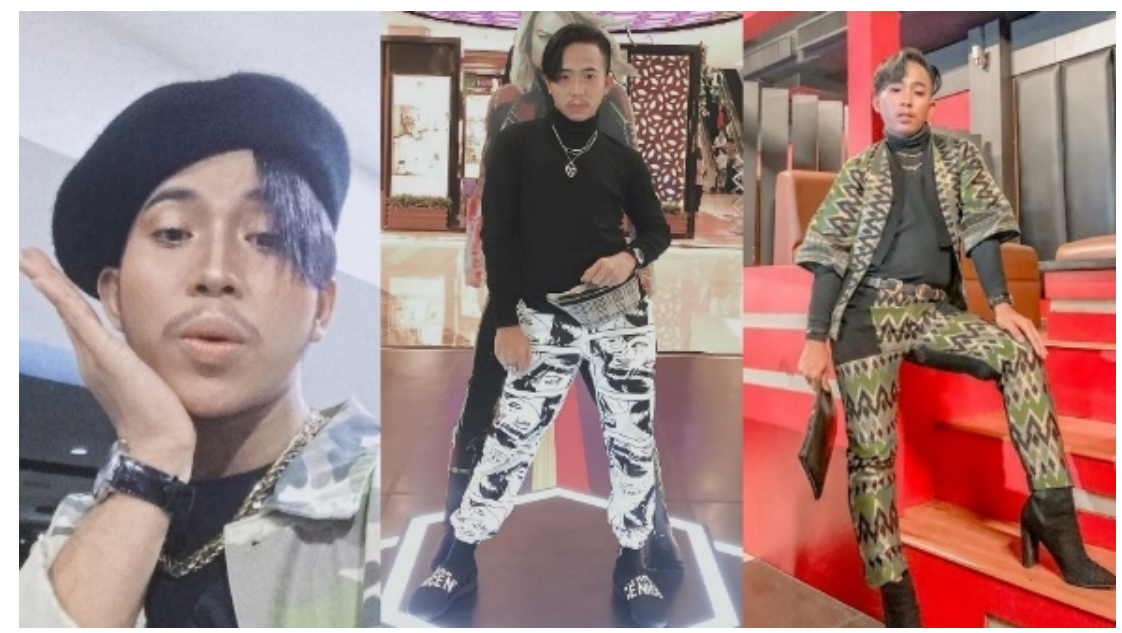

Gambar 7. Gaya androgini Agung ${ }^{15}$

Ikky (21 tahun) juga berdandan untuk menunjang penampilannya. la senang bereksperimen dengan highlighter, perona pipi, dan perona mata, ia juga menyukai lipstik dengan warna cerah agar dirinya tidak terlihat pucat. Namun, ia tetap berambut pendek dan berkumis, kemudian kerap mengenakan sepatu Vans khusus laki - laki yang menunjukkan sisi maskulinnya. Dalam berpakaian, ia lebih fleksibel, ia senang dengan pakaian dan celana bermotif dan polos, berkaos oblong berukuran slim fit maupun oversized. Sling bag, jam tangan, kalung, dan cincin adalah assesoris yang menunjang fashion androgininya (lihat Gambar 8).

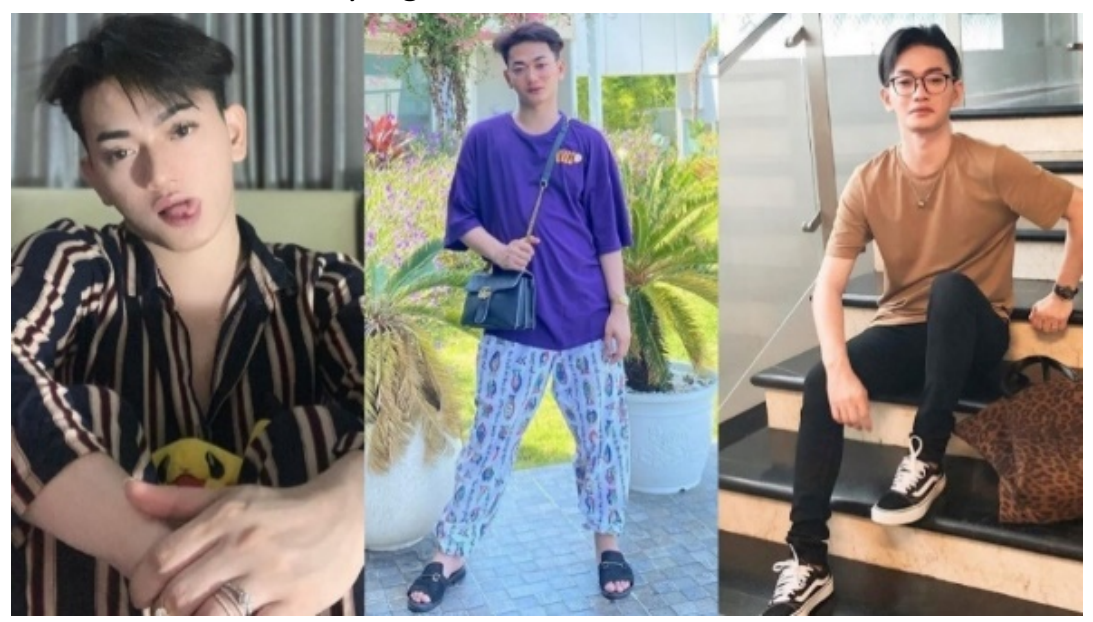

Gamba 8. Gaya androgini Ikky ${ }^{16}$

Contoh lainnya adalah Joshua (22 tahun) yang gemar tampil eksentrik dari kepala hingga kaki. Untuk dandanan, ia lebih detail dalam penggunaan produk, dari foundation, concelear, bedak, blush on, highlighter, maskara, pensil alis, dan lipstick untuk menunjang penampilannya. Joshua gemar crop-top (baju yang memperlihatkan pinggang, pusar, atau perut) dan kaos polos. Untuk bawahan Joshua seringkali mengenakan legging, celana jins, celana kain dan berbagai model celana unik lainnya (lihat Gambar 9). Joshua juga senang menggunakan tas (mulai dari tote bag, guilted bag, hingga baguette

\footnotetext{
15 https://www.instagram.com/carlotcx/, diakses tanggal 14 Maret 2020.

${ }^{16}$ https://www.instagram.com/1.kk.y/, diakses tanggal 14 Maret 2020.
} 
bag). la juga lebih fleksibel, ia menggunakan sepatu kets dan sepatu bertumit tinggi yang biasa digunakan oleh perempuan. Anting dengan beragam model termasuk yang berbentuk lingkaran besar, kalung, dan kacamata hitam merupakan bagian dari fashionnya yang eksentrik. Sedangkan untuk sisi maskulin Joshua memakai hoodie atau jaket yang memiliki penutup kepala berukuran besar yang didesain khusus bagi laki-laki, dan tetap mempertahankan rambut pendek dan tentunya kumis tipis khas maskulin.

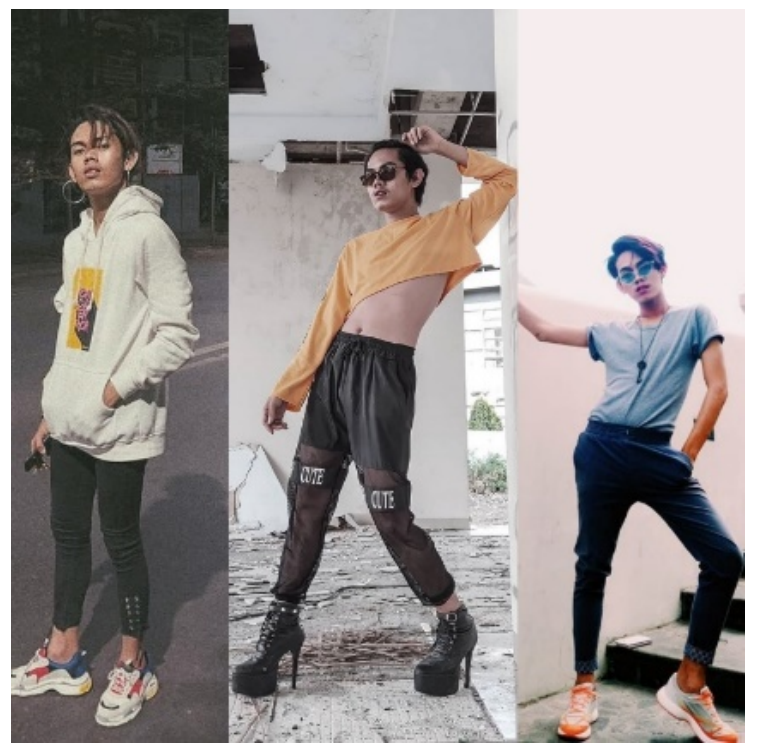

Gambar 9. Gaya Androgini Joshua ${ }^{17}$

\section{Motif Androgini Mengekspresikan Dirinya}

Motif merupakan konfigurasi makna yang menjadi landasan untuk bertindak, oleh karena itu, motif menjadi penting dalam setiap tindakan sebagai peninjau diri (Taufik 2014:76). Menurut Alfred Schutz (1970:53), motif dibagi kedalam dua bagian, yaitu motif karena (because-motives) yang merujuk kepada pengalaman masa lalu yang menjadi alasan pelaku dan motif untuk (in order to motive) yang merupakan tujuan yang ingin dicapai yang meliputi maksud, rencana, harapan, dan minat yang diinginkan oleh androgini (Nindito 2013:14). Kedua motif karena (becausemotives) dan motif untuk (in order to motive)ini akan dibahas pada sub-sessi berikut ini.

\section{Motif Karena (Because Motives)}

"Motif karena" merupakan alasan yang mendasari seseorang untuk melakukan suatu hal. Dalam konteks ini terkait dengan motif yang mendasari kenapa laki-laki androgini menunjukkan ekspresi gendernya. Ada sejumlah alasan yang dikemukakan mulai dari pengaruh peer group, rasa nyaman, kepuasan terhadap diri sendiri, dan profesionalitas.

\section{Pengaruh Peer Group}

Agen sosialisasi yang pertama adalah keluarga dan semakin besar anak mulai bergaul dengan orang di luar keluarga, yakni dengan orang yang sebaya dengannya (peer group). Sebagai salah satu agen sosialisasi, peer group berperan signifikan dalam melembagakan perilaku berdasarkan gender.

Botty Boyz adalah sebuah kelompok androgini yang terbentuk berdasarkan minat dan bakat para anggotanya. Awalnya kelompok ini dibentuk oleh Agung, Joshua, Ikky yang tergabung dalam kelompok ekstrakulikuler cheerleader sewaktu mereka

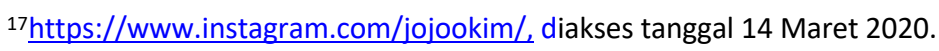


masih SMP. Kemudian kesukaan mereka terhadap dance membuat ketiganya mengambil ekstrakurikuler yang sama setelah masuk SMA. Ketika mereka lulus mereka membentuk kelompok dance yang diberi nama Botty Boyz dan merekrut anggota di luar sekolah mereka. Setelah cukup terkenal di bidang dance, Botty Boyz mulai merambah ke dunia fashion (lihat Gambar 10). Peer group di bawah bendera Botty Boys ini berperan signifikan dalam mengekspresikan androginitas mereka.

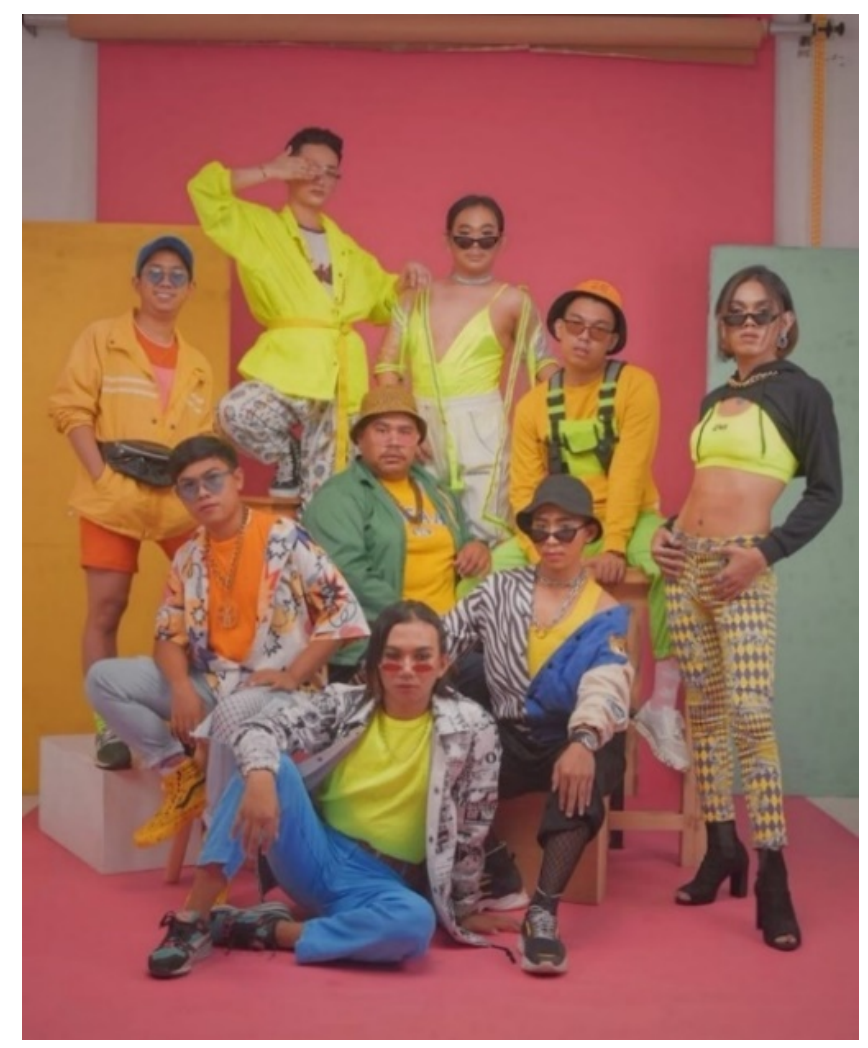

Gambar 10. Botty Boyz ${ }^{18}$

Begitu pula dengan Adhe (22 tahun), misalnya, mulai menekuni bidang modelling ketika masuk SMA, saat itulah ia banyak bertemu dengan laki-laki yang memerhatikan fashionnya (lihat Gambar 11). Sejak itu Adhe lebih berani untuk berekspresi dengan memadukan gaya busana khas perempuan dan laki-laki yang menjadi ciri khas laki-laki androgini.

${ }^{18}$ https://www.instagram.com/bottyboyz.official/, diakses tanggal 23 April 2020. 


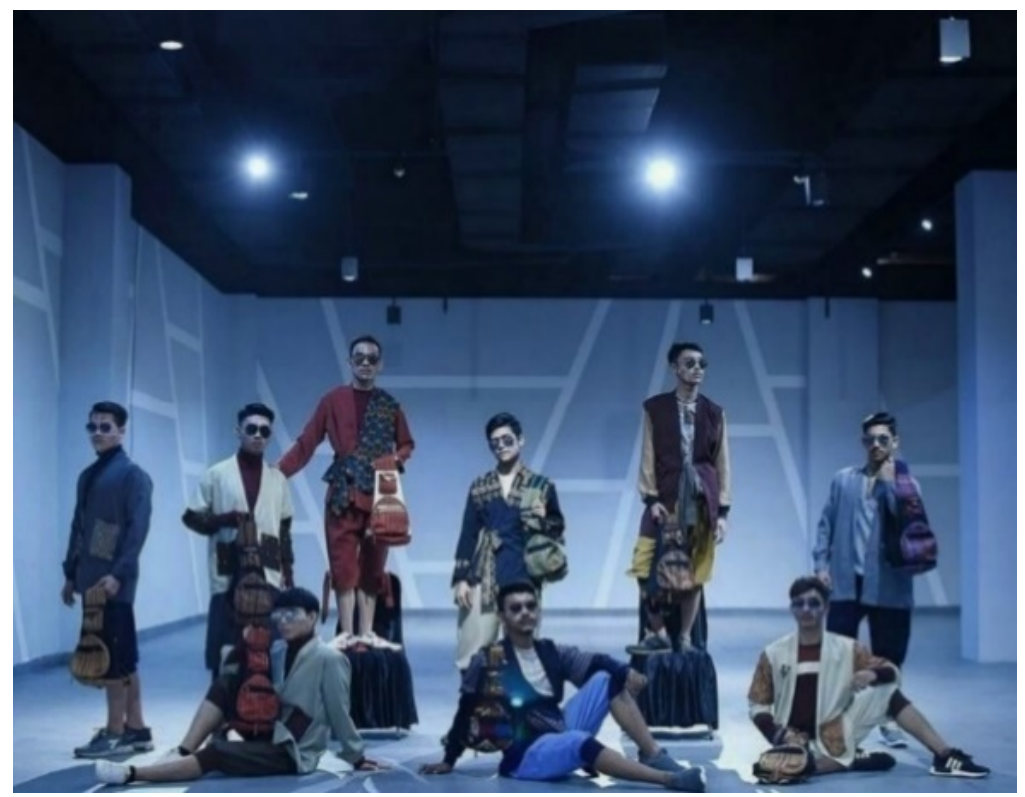

Gambar 11. Adhe dan rekan modelnya ${ }^{19}$

Studi Hartup dan Stevens (1999:79) menegaskan bahwa komunikasi pertemanan antar gender relatif konsisten dan memiliki teman bergaul adalah suatu hal yang positif karena teman dapat mendorong rasa percaya diri dan menolong dalam mengatasi depresi. Dalam konteks androgini, ini mengindikasikan signifikannya pengaruh peer group dalam mengekspresikan androginitas dan membuat mereka dapat lebih leluasa dan percaya diri dalam berekspresi.

\section{Rasa Nyaman}

Alasan lain kenapa laki-laki mengekpresikan androgini adalah karena mereka merasa nyaman. Secara psikologis, kenyamanan menurut Kolcaba (2010:58) merupakan suatu kondisi seseorang yang merasa dapat diterima sebagaimana adanya dan dapat mengekspresikan dirinya dengan bebas. Lakilaki androgini merasa tidak nyaman jika tidak menjadi diri sendiri dan ketidaknyamanan itulah yang seringkali sulit dipahami oleh orang lain.
Adhe (22 tahun), misalnya, menceritakan perjalanannya dalam menemukan jati dirinya. la pernah mencoba menjadi laki-laki seutuhnya, berekspresi maskulin seperti konstruksi sosial laki-laki pada umumnya. Namun, ia merasa tidak nyaman, sehingga akhirnya ia mendatangi psikiater untuk menanyakan hal tersebut. Menurut psikiater tersebut, setiap manusia mempunyai kromosom $X$ dan kromosom $Y$, yang berbeda satu sama lain. Hal ini sesuai dengan pernyataan seorang ahli genetika Jenny Graves-Penerima Prime Minister's Prize for Science tahun 2017 yaitu jika ada seorang lakilaki bersifat keperempuanan, maka itu bukanlah hal yang salah. Laki-laki yang feminin adalah karena kromosom $X$ pada laki-laki tersebut lebih dominan daripada kromosom $Y$. Begitu juga dengan perempuan yang bersikap kelaki-lakian, kromosom $\mathrm{Y}$ pada perempuan lebih dominan dibandingkan kromosom $\mathrm{X}^{20}$. Sedangkan dari segi penampilan, Adhe (22 tahun) merasa tidak nyaman mengenakan kaus oblong karena ia kurang percaya diri dengan

\footnotetext{
${ }^{19} \mathrm{https://www.instagram.com/adhe} \mathrm{caesaryo/tagged/,} \mathrm{diakses} \mathrm{tanggal} 5$ Mei 2020.

${ }^{20}$ https://almi.or.id/2018/11/10/seorang-ahli-genetika-jelaskan-apa-yang-membuat-anda-menjadi-laki-laki-atauperempuan/, diakses tanggal 23 April 2020.
} 
tubuhnya yang kurus. Oleh karenanya, Adhe lebih memilih mengenakan kemeja atau sweater berwarna cerah dan celana model high waist dalam berpenampilan.

Hal serupa juga terjadi pada Abe (24 tahun) yang merasa nyaman dan percaya diri saat mengenakan pakaian berwarna cerah dengan motif floral yang menurutnya lebih feminin ketimbang maskulin. Selain itu, ia juga merasa nyaman dengan cara berjalan yang gemulai daripada memaksakan cara berjalan yang tegak dan tegas seperti ekspektasi sosial bagi laki-laki dalam berprilaku.

\section{Kepuasan Diri}

Kepuasan menjadi diri sendiri didasarkan cara pandang seseorang yang positif mengenai kehidupannya. Rajif (23 tahun), misalnya, beranggapan jika seseorang membentuk dirinya dengan ekspektasi orang lain, maka ia akan selalu bergantung dengan perkataan orang lain dan hanya akan menjadi "orang lain".

Agung (20 tahun) merasa dirinya sudah dewasa dan berhak menentukan identitas dirinya sebagai laki-laki androgini sesuai dengan keinginannya, walaupun pilihan tersebut berbeda dengan orang lain. Agung merasa puas, pertama, karena ia tidak membohongi dirinya; kedua, karena ia menjadi dirinya sendiri. Meskipun demikian, ia tetap merasa sebagai seorang laki-laki, yang juga memiliki sisi feminin.

Ami (20 tahun) merasa bahwa meski pada awalnya ia dijauhi oleh teman-temannya karena makin berani mengekspresikan androginitasnya, namun ia tetap merasa puas telah menjadi dirinya sendiri. Ami pun beranggapan bahwa teman baik adalah orang yang mendukung kebahagiaan temannya.

Joshua (22 tahun) mengekspresikan pandangannya yang lebih radikal bahwa tidak ada salahnya menjadi berbeda dari orang lain. Meskipun ia menjadi berbeda dibandingkan dengan laki-laki lain, ia merasa lebih memilih jujur pada dirinya sendiri dan percaya diri dengan keberbedaannya dibandingkan mengikuti konstruksi sosial sebagai laki-laki yang justru membuatnya menjadi orang lain. la berprinsip bahwa selama dirinya tidak melakukan tindakan yang merugikan orang lain dan tidak melanggar hukum, ia akan tetap menjadi dirinya sendiri, menjadi seorang lakilaki androgini.

\section{Profesionalitas}

Banyak dari laki-laki androgini menggunakan pakaian yang lebih feminin untuk profesionalitas. Banyak tawaran yang datang kepada mereka untuk melibatkan mereka dalam beragam acara. Biasanya mereka diundang untuk menampilkan penampilan unik yang hanya bisa dilakukan oleh laki-laki androgini, misalnya, menjadi Master of Ceremony (MC), penari, atau sebagai model dalam suatu acara pagelaran busana dll. Kelompok androgini Botty Boyz, misalnya, yang menekuni bidang dance, pekerjaan tersebut mengharuskan anggotanya tampil menarik sesuai konsep dance yang ditentukan oleh penyelenggara (lihat Gambar 12). Salah seorang anggotanya bernama Jeje (21 tahun) mengungkapkannya sebagai berikut:

Kalau memang harus mengcover tarian girlband, ya kita harus total dong. Ada tarian girlband yang gayanya harus centil, ada juga gayanya harus seksi dan kita harus benarbenar bisa mengekspresikan itu. Belum lagi kostumnya yang juga harus disesuaikan. Apalagi di dunia hiburan kita kan dituntut untuk profesional jadi ya kita harus mampu melakukannya dengan sempurna. 

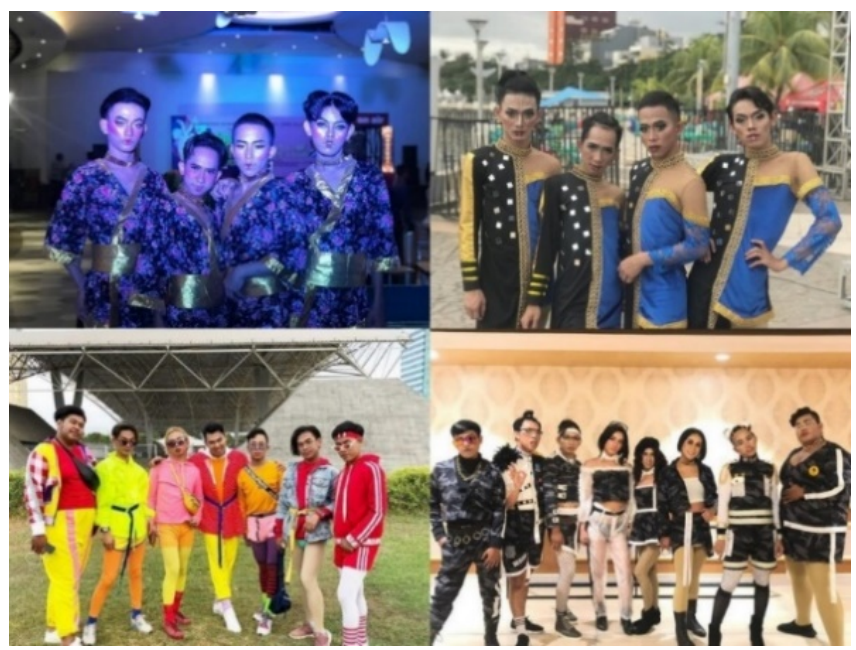

Gambar 12. Botty Boyz di berbagai acara dance ${ }^{21}$

Hal serupa diungkapan oleh Adhe (21 tahun) yang menekuni bidang modelling dan aktif sebagai master of ceremony (MC). la beranggapan bahwa seorang pembawa acara harus lebih menonjol dibanding penontonnya, maka dari itu ia mengenakan gaya androgini dalam penampilannya, seperti kimono ikat (feminin) yang padukan dengan kemeja hitam (maskulin), seperti nampak pada Gambar $\mathbf{1 3}$ berikut ini.

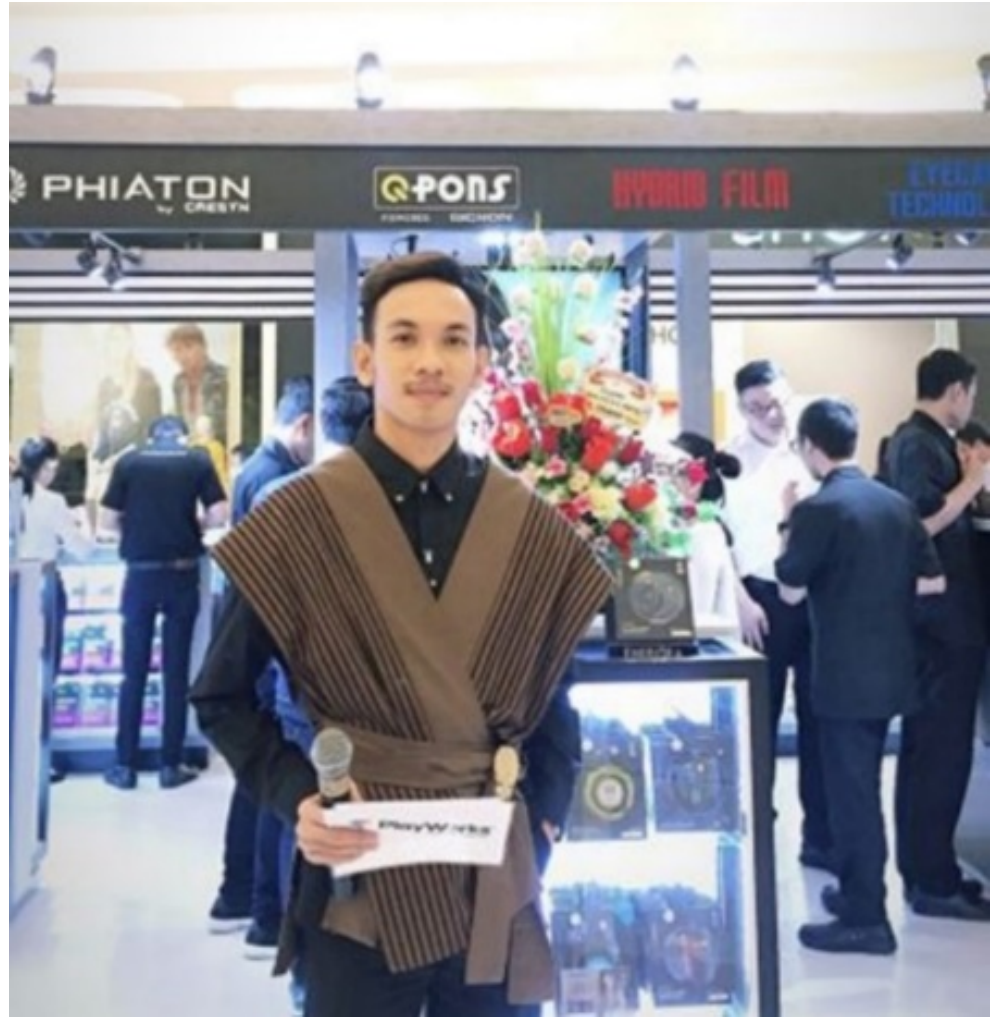

Gambar 13. Penampilan Adhe Caesaryo sebagai $\mathrm{MC}^{22}$

\footnotetext{
${ }^{21}$ https://www.instagram.com/bottyboyz.official/, diakses tanggal 14 Mei 2020.
}

22 https://www.instagram.com/adhe caesaryo/, diakses tanggal 15 Mei 2020. 
Selain menjadi MC, Adhe juga menekuni bidang modelling. Berprofesi sebagai model dituntut untuk merepresentasikan sebuah imej sesuai arahan fotografer. Di Indonesia, ada beberapa nama model yang dikenal sebagai laki-laki androgini, baik untuk model foto atau catwalk, seperti Darrel Ferhostan, Jovi Adhiguna, Lie Buntaran, Andreas Lukita, dan Ichsan Rindengan Dalam dunia modeling, model androgini menggunakan busana perempuan sebagai sisi feminin, namun tidak diperkenankan menggunakan bra atau tambahan dada sebagai bentuk payudara karena dada datar adalah simbol maskulinitas yang tetap ditampilkan. Ini mengindikasikan bahwa model androgini tetaplah seorang laki-laki secara fisik, ${ }^{23}$ namun sisi feminin dan maskulin ditampilkan secara bersamaan.

Darell Ferhostan merupakan model androgini pertama Indonesia. Darell memiliki tinggi $185 \mathrm{~cm}$ dan berat badan $63 \mathrm{~kg}$ ditambah dengan kulitnya yang putih, garis wajah yang lembut, dan rambut hitam panjangnya membuat ia terlihat terlalu feminin sebagai model pria, tetapi lekuk tubuhnya juga terlalu maskulin bila dikategorikan sebagai model perempuan. Itulah keunikannya yang membuat namanya bersinar sebagai Top Model tidak hanya ditanah air, tetapi juga didunia internasional seperti saat ini. (lihat Gambar 14). Darell Ferhostan berhasil go international dengan menjadi model di Prancis, di bawah agensi model Rock Men Models.

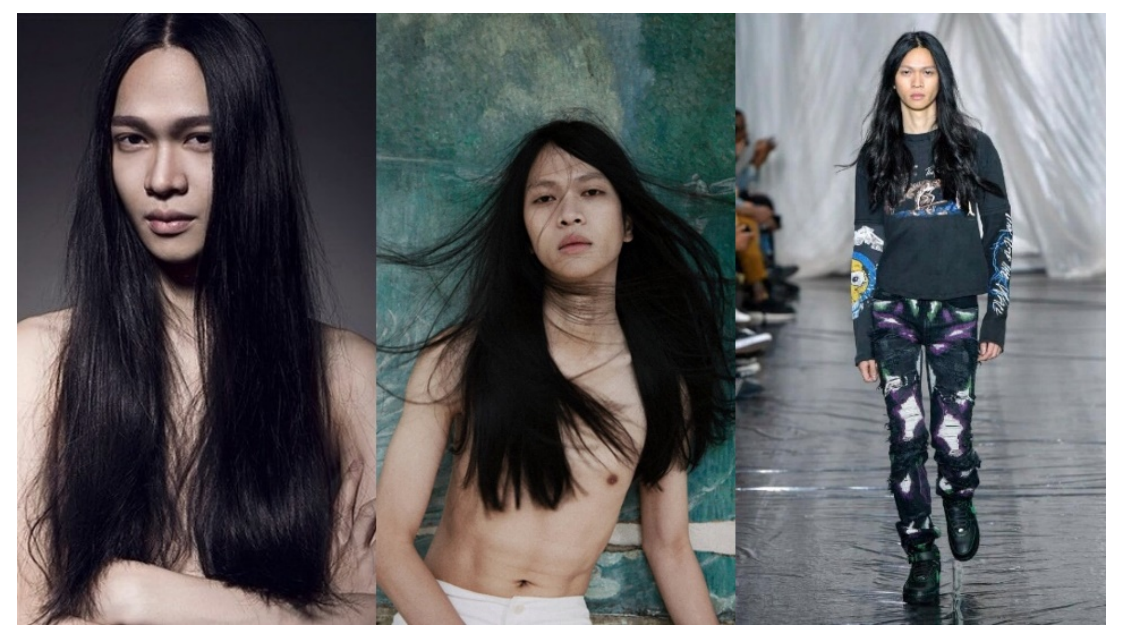

Gambar 14. Darell Ferhostan ${ }^{24}$

\section{Motif Untuk (In Order To Motive)}

Dalam mengekspresikan androginitas, selain motif karena (because-motives), laki-laki androgini juga memiliki motif untuk (in order to motive), yang bertujuan untuk mencapai sesuatu. Temuan penelitian ini menunjukkan adanya dua tujuan dalam mengekspresikan androginitas, yakni ingin dipandang normal dan ingin diterima oleh masyarakat.

\section{Ingin Dipandang Normal}

Androgini adalah bentuk ekspresi gender seseorang. Laki-laki androgini umumnya merasa tidak ada yang salah dengan ekspresi mereka. Namun, sesuatu yang berbeda dan tidak biasa justru akan menimbulkan pandangan dan asumsi negatif dari masyarakat yang dianggap tidak memahaminya. Keinginan laki-laki androgini adalah bebas berekspresi dan tetap dipandang normal. Hal ini karena masyarakat umumnya tidak memahami apa

\footnotetext{
${ }^{24} \mathrm{http}: / /$ lensa.id/ini-dia-4-sosok-androgini-indonesiayang-sukses-di-fashion-internasional/35945/, diakses tanggal 5 April 2020.

${ }^{23}$ https://talkseehear.wordpress.com/2015/10/30/d alisme-tubuh-model-androgini-antara-karakterpribadi-dan-profesi/, diakses tanggal 5 April 2020
} 
dan bagaimana sebenarnya mereka yang berpenampilan androgini. Ini dapat dilihat orang bertemu dengan seseorang yang berpenampilan androgini. Mereka melihatnya dengan rasa heran bahkan mengejek.

Hal ini didukung oleh fakta bahwa Indonesia adalah negara yang mayoritas Muslim, yang umumnya menganggap bahwa identitas dan ekspresi gender seseorang harus selaras dengan jenis kelamin yang terkodratkan (given). Joshua (22 tahun) membenarkan hal tersebut, bahwa secara agama memang ekspresi gendernya dianggap salah. Namun, jika merujuk pada semboyan bangsa Indonesia, yaitu Bhinneka Tunggal Ika (berbeda-beda, tapi tetap satu), seharusnya masyarakat Indonesia lebih toleran terhadap perbedaan, termasuk terhadap eksistensi androgini. Setidaknya jika ada yang tidak setuju dengan ekspresi androgininitas seseorang, mereka tidak menyakiti secara verbal maupun fisik selama laki-laki androgini tidak mengganggu mereka. Pandangan Joshua menunjukkan ambivalensi. Di satu sisi, ia menganggap penampilan androgini sesuatu yang salah, di sisi lain, ia menganggap bahwa berpenampilan androgini adalah hak individu.

Agar dapat dianggap normal, laki-laki androgini senantiasa berupaya untuk membangun citra yang baik dan positif dengan cara menjadi pribadi yang ramah dan menyenangkan, tidak mudah terbawa emosi ketika ada yang menghujatnya, tidak melakukan hal-hal yang menyimpang, seperti melakukan kekerasan atau tindakan kriminal lainnya dan berprestasi di bidang yang mereka tekuni.

Ingin Diterima Masyarakat

Laki-laki androgini, sebagaimana makhluk manusia lainnya, juga berkeinginan agar keberadaan mereka diterima oleh masyarakat. Irvan (21 tahun), misalnya, berharap dapat berada di lingkungan masyarakat yang menyadari keberagaman gender, identitas gender, dan ekspresi gender agar mereka merasa nyaman secara psikis, dan terutama aman secara sosial dalam mengekspresikan gender mereka, yang dalam konteks androgini, terutama diekspresikan melalui fashion.

Rajif (23 tahun) menganggap bahwa stigma terhadap laki-laki androgini sebagai seorang banci/bencong disebabkan oleh norma sosial yang mengonstruksikan laki-laki dengan penampilan maskulin. Stigma semacam ini dikenal dengan istilah toxic masculinity (maskulinitas beracun). Toxic masculinity berawal dari stigma bahwa laki-laki tidak dapat mengekspresikan emosi secara terbuka dan mereka harus tangguh dan berpenampilan jantan sepanjang waktu. Halhal di luar maskulinitas akan membuat mereka terlihat "lemah" (Elliott 2019:3).

Upaya untuk dapat diterima secara sosial mulai dilakukan. Misalnya, dalam bentuk tantangan di media sosial TikTok dengan tagar \#EndToxicMasculinity dan slogan "Petition for Indo boys to do this" (petisi untuk anak laki-laki di Indonesia untuk melakukan ini). Pembuatnya adalah mereka yang mendukung paham bahwa laki-laki tidak harus dipaksakan menjadi maskulin. Tantangan ini viral dengan unggahan dari 4.926 video dan 16 juta penonton pada tanggal 17 Juli 2020 (lihat Gambar 15). Mereka berharap dengan berbagai upaya yang dilakukan agar dapat diterima oleh masyarakat paling tidak dapat mengeliminir atau bahkan menghilangkan stigma terhadap diri mereka yang mengekspresikan gender secara berbeda dari cara mengerekspresikan gender secara normatif. 


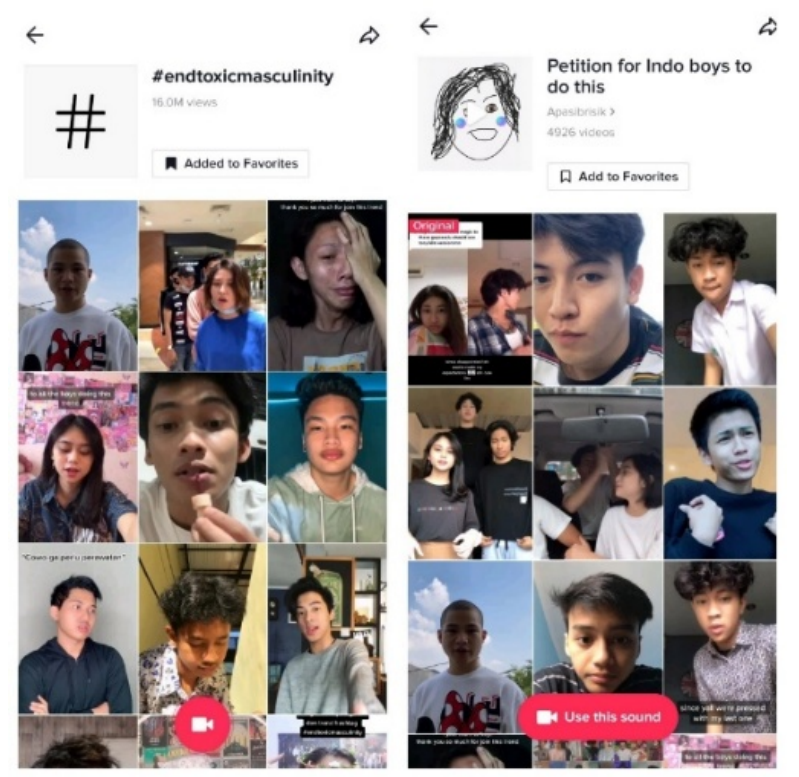

Gambar 15. End Toxic Masculinity Challenge ${ }^{25}$

Rajif (23) berharap akan ada lebih banyak dukungan seperti itu kepada mereka, mereka juga berharap masyarakat lebih memahami tentang gender, identitas gender dan ekspresi gender. Tingkah laku dan sikap yang ditampakkan, serta assesori yang digunakan oleh laki-laki androgini adalah terkait dengan ekspresi gender mereka, dan tidak berassosiasi dengan orientasi seksual mereka.

\section{Kesimpulan}

Laki-laki androgini bukanlah transgender karena mereka tidak ingin menjadi "seperti perempuan" sebagaimana yang diobsesikan oleh transgender. Di samping itu, laki-laki androgini mengklasifikasikan diri mereka lebih tinggi daripada transgender, dari segi penampilan maupun kelas sosial.

Meskipun laki-laki androgini dapat mengekspresikan androginitas mereka melalui perilaku, minat dan bakat, namun fashion merupakan aspek yang paling signifikan yang mengindikasikan androginitas seseorang. Lakilaki androgini lebih mengekspresikan androgini melalui fashion daripada yang lain karena melalui fashion eksistensi mereka mudah dikenali karena merupakan perpaduan antara karakter maskulin dan feminin.

Fashion androgini terbagi atas dua, less masculine-more feminine and less femininemore masculine. Jika yang pertama laki-laki androgini lebih menonjolkan sisi feminin dibandingkan sisi maskulin, maka yang kedua androgini yang lebih menonjolkan sisi maskulin dibandingkan sisi feminin. Apakah seorang lakilaki androgini lebih feminin atau lebih maskulin, tergantung pada penampilan mereka dan persepsi mereka terhadap apa yang ditampilkan.

Motif laki-laki androgini terdiri atas "motif karena" ("because-to-motive") dan "motif untuk" ("in-order to motive"). Jika yang pertama mencakup pengaruh peer group, rasa nyaman, kepuasan diri, dan profesionalisme; maka yang kedua meliputi harapan untuk diterima secara sosial dan diterima sebagai orang normal.

\section{Daftar Pustaka}

Altilio, M. dan Otis, G. 2011. Oxford textbook of palliative social work. Oxford: Oxford University Press.

${ }^{25}$ https://www.tiktok.com/tag/endtoxicmasculinity?lang=id, diakses tanggal 5 Mei 2020. 
Anggraini, D. 2013. Representasi Identitas Androgini dalam Majalah Fesyen. Skripsi, Fakultas IImu Sosial dan IImu Politik, Universitas Airlangga, Surabaya.

Anindya, A. 2016. "Gender Fluid dan Identitas Androgini dalam Media Sosial", TINGKAP, Oktober, 12(2):107118.

Aningpasca, A. 2015. "Self Presentation Model Androgini dalam Lingkungan Pertemanan", Jurnal eKomunikasi, Agustus, 3(2):1-15.

Arnold, R. 2001. Fashion, desire and anxiety: Image and morality in the 20th century. London: Rutgers University Press.

Barnard, M. 2010. Fashion statements: Communication and culture. New York: Palgrave Macmillan.

Budiantoro, H. 2016. Fashion Androgini dalam Pendekatan Fotografi Editorial di Kota Bandung. Skripsi, Fakultas Seni dan Sastra, Universitas Pasundan, Bandung.

Chandra, C. 2018. "Konsep Diri dan Pola Komunikasi Antar Pribadi Seorang Androgini di Dalam Masyarakat", EJournal Koneksi, Oktober, 1(1): 41-45.

Dean, M. 2017. "Extending the legacy of Sandra Bem: Psychological Androgyny as a Touchstone Conceptual Advance for the Study of Gender in Psychological Science", Sex Roles, Desember, 76(11):643-654.

Fhebrianty, N. dan Oktavianti, R. 2019. "Representasi Identitas Androgini di Media Sosial", EJournal Koneksi, Maret, 3(1):274-281.

Funay, C. M. 2018. "Representasi Androgini Jovi Adhiguna di Video Blog
YouTube", Interaksi Online, Maret, 6(2):56-66.

Goenawan, F. 2007. "Media, Teknologi Dan Masyarakat Gender \& Website", Scriptura, Juli, 1(2):71-81.

Hartup, W. dan Stevens, N. 1999. "Friendships and Adaptation Across the Life Span", Current directions in psychological science, Juni, 8(3):76-79.

Kolcaba, Katharine, dan Carol. 2006. "Comfort theory: A unifying framework to enhance the practice environment". JONA: The Journal of Nursing Administration, November, 36(11):538-544.

Nahata, L. 2017. "Low Fertility Preservation Utilization Among Transgender Youth", Journal of Adolescent Health, Juli, 61(1):40-44.

Parent, Teresa, dan Aaron. 2019. "Social Media Behavior, Toxic Masculinity, and Depression", Psychology of Men \& Masculinities, Juli, 20(3):277.

Perkasa, Syahdad, Ayu, dan Nyoman. 2017."Analisis Penggunaan Fashion Androgini Sebagai Media Komunikasi di Kota Denpasar", E-Jurnal Medium, September, 1(1):1-20.

Pradika, Gabrielle, Ido, dan Fanny. 2019. "Star Studies terhadap Kontruksi Image Androgynous YouTuber Jovi Adhiguna Hunter", Scriptura, Juli, 9(1):35-42.

Schutz, A. 1970. Alfred Schutz on phenomenology and social relations. United States: Central Intelligence Agency.

Sitanggang, A. 2020. "Androgini: Popularitas dan Eksistensi Bagi Remaja di Era Digital". Jurnal Spektrum Komunikasi, Juni, 8(1):30-44. 